\title{
Hjartað ræður för
}

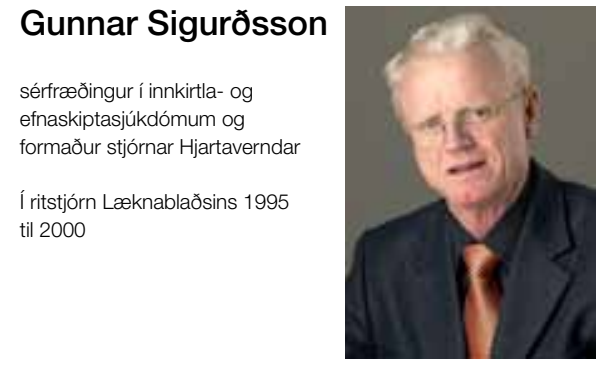

gunnars@landspitali.is

Kransæðasjúkdómar hafa verið á undanhaldi á Íslandi síðan um 1980. Sjúkdómurinn hafði pá verið í miklum vexti eftir 1950 og náð hámarki um 1970. Nú er svo komið að kransæðasjúkdómar eru ekki lengur algengasta dánarorsök á Íslandi og dánartíðni af peirra völdum komin niður fyrir pað sem hún var um 1950 samkvæmt dánarmeinaskrá Hagstofunnar og síðar Embættis landlæknis. Pessi lækkun hefur fyrst og fremst náðst með bættri pekkingu almennings og heilbrigðisstétta á eðli sjúkdómsins og líklegum áhættupáttum, svo og viðbrögðum heilbrigðisyfirvalda og matvælaiðnaðarins. Af pessu hafa leitt jákvæðar lífsstílsbreytingar að ýmsu leyti en einnig skiptir íhlutandi meðferð með lyfjum og skurðaðgerðum vissulega máli.

Kringumstæðurnar hafa pví breyst verulega frá pví að kollegar okkar, Sigurður Samúelsson, Snorri Páll Snorrason og Theódór Skúlason á lyflækningadeild Landspítalans, stóðu saman að pví að sporna gegn kransæðafaraldrinum fyrir réttum 50 árum með pví stórvirki að stofna Hjartavernd á haustmánuðum 1964.

Umrædd breyting til batnaðar hefur aukið ævilíkur Íslendinga um nokkur ár og einkenni sjúkdómsins koma að jafnaði fram síðar á ævinni en áður. Prátt fyrir pað pjást púsundir Íslendinga af pessum sjúkdómi sem einnig veldur mörgum ótímabærum dauðsföllum. Pví er mikilvægt að vera vel á varðbergi og efla forvarnir og tryggja sem bestan árangur meðferðar.

Í pessu tölublaði Læknablaðsins birtast tvær mikilvægar greinar um kransæðasjúkdóma. Læknar hjartaskurðdeildar Landspítala sýna fram á góðan árangur kransæðahjáveituaðgerða á sjúklingum 50 ára og yngri á tímabilinu 2001-2012. ${ }^{1}$ Pessi aldurshópur var um 6\% alls sjúklingahópsins og athyglisvert er að petta hlutfall hélst óbreytt út rannsóknartímabilið. Hér er um afturskyggna rannsókn að ræða og pví ekki unnt að sýna fram á hvaða áhættupættir tengdust snemmkomnum kransæðasjúkdómi og ættarsagan er ekki kunn. Aðdáunarvert er hvað læknar hjartaskurðdeildarinnar hafa verið iðnir við að kortleggja árangur aðgerða sinna á síðustu árum, sem er mjög mikilvægt í gæðaeftirliti og samanburði við erlendar stofnanir.

Hin greinin er ítarleg yfirlitsgrein um kransæðasjúkdóminn í heild sinni (pó aðeins fyrri hlutinn í pessu tölublaði). ${ }^{2}$ Athygli vekur að pessi samantekt er sameiginlegt framtak hjartaskurðlækna og hjartalyflækna Landspítala enda er greinunum ætlað að ná yfir flesta pætti sjúkdómsins. Greinarnar eru ætlaðar öllum heilbrigðisstéttum, sem er vel pví að fræðsla heilbrigðisstétta skiptir miklu máli varðandi alla frampróun.

Í forvarnahluta greinarinnar er lögð áhersla á bæði lýðgrundaðar og einstaklingsmiðaðar forvarnir og bent á að bestur árangur náist með pví að beita báðum aðferðum. Höfundar benda á árangur lýðgrundaðra aðgerða hér á landi, sem átt hafa sinn pátt í minnkandi reykingum á Íslandi. Á síðustu áratugum síðustu aldar mátti rekja eitt dauðsfall á dag á Íslandi til reykingatengdra sjúkdóma samkvæmt gögnum Hjartaverndar. ${ }^{3}$ Í dag nálgast pað hins vegar að rekja megi eitt dauðsfall annan hvern dag til reykinga. Pví eru nú um 150 færri dauðsföll árlega vegna minni reykinga í samanburði við árið 1981. Samkvæmt gögnum Hjartaverndar reykja pó enn um 20\% Íslendinga á kransæðaaldrinum og pví er hér mikið verk að vinna.

Prátt fyrir samfellda pyngdaraukningu Íslendinga síðastliðinn aldarfjórðung og tvöföldun á tíðni sykursýki af tegund tvö samfara pví ,hefur nýgengi kransæðasjúkdóma haldið áfram að lækka4 (niðurstöður vantar pó fyrir allra síðustu ár). Veldur par mestu að heildargildi kólesteróls í blóði (sem er óháð líkamspyngd) hefur haldið áfram að lækka sem nemur alls 1,5 mmol/L til ársins $2008^{5}$ og skýrir um priðjung lækkunar á dánartíðni af völdum kransæðasjúkdóma á síðustu áratugum. Væntanlega tengist petta æskilegum breytingum á mataræði sem lýst er í umræddri yfirlitsgrein.

Hins vegar eru nú teikn á lofti um að pessi lækkun hafi stöðvast og meðal kólesterólgildi jafnvel hækkað á ný samkvæmt óbirtum gögnum Hjartaverndar fyrir árið 2010. Hugsanlega tengist pessi viðsnúningur peim mataræðisbreytingum sem vart hefur orðið hér á landi síðustu árin en áhrif pess á tíðni kransæðasjúkdóma kunna að koma fram nokkrum árum síðar. Petta áréttar pví mikilvægi pess að halda áfram reglubundnum mælingum á áhættupáttum kransæðasjúkdóma í stóru pýði og skráningu kransæðasjúkdóma á Íslandi. Enn fremur undirstrikar petta mikilvægi pess að mataræðiskannanir verði framkvæmdar á Íslandi með reglubundnum hætti. Engan veginn er nægjanlegt að framkvæma pær á 10 ára fresti eins og verið hefur.

Í yfirlitsgreininni eru einnig raktar nýjungar í rannsóknum og greiningu samfara vaxandi pekkingu og dýpkandi skilningi á pessum mikilvæga sjúkdómi. Notkun pessara greiningaraðferða hér á landi væri vissulega verð frekari umræðu.

Fróðlegt verður að lesa um mismunandi meðferð kransæðasjúkdóms í seinni hluta pessarar vönduðu og pörfu yfirlitsgreinar.

\section{Heimildir}

1. Árnadóttir LÓ, Axelsson TA, Helgason D, Jóhannesdóttir $\mathrm{H}$, Aðalsteinsson JA, Geirsson A, et al. Árangur kransæðahjáveituaðgerða hjá sjúklingum fimmtíu ára og yngri. Læknablaðið 2014; 100: 651-6.

2. Guðbjartsson T, Andersen K, Danielsen R, Geirsson A, porgeirsson G. Yfirlitsgrein um kransæðasjúkdóm - fyrri hluti: Faraldsfræði, meingerð, einkenni og rannsóknir til greiningar. Læknablaðið 2014; 100: 667-76.

3. Handbók Hjartaverndar hjarta.is

4. Aspelund T, Gudnason V, Magnusdottir BT, Andersen K, Sigurdsson G, Thorsson B, et al. Analysing the large decline in coronary heart disease mortality in the Icelandic population aged 25-74 between the years 1981 and 2006. PLoS One 2010; 5: 213957.

5. Thorsson B, Steingrimsdottir L, Halldorsdottir S, Andersen K, Sigurdsson G, Aspelund T, et al. Changes in total cholesterol levels in Western societies are not related to statin, but rather dietary factors: the example of the Icelandic population. Eur Heart J 2013; 34: 1778-82.

Coronary heart disease in the front

Professor Gunnar Sigurdsson physician, chairman of the Icelandic Heart Association, former professor of Endocrinology University of Iceland 